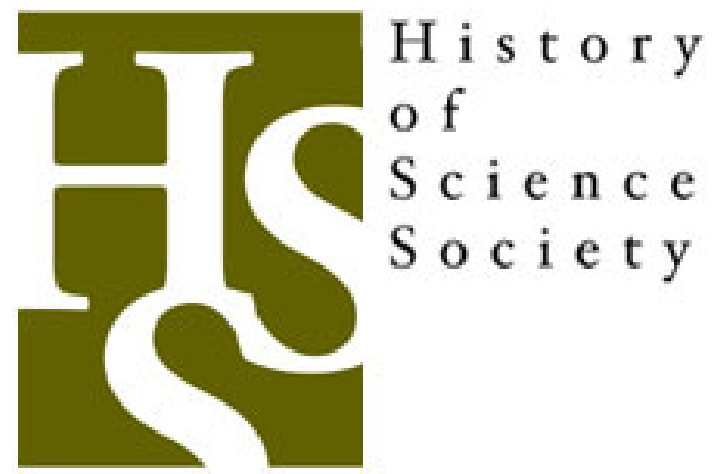

Lists as Research Technologies

Author(s): Staffan Müller-Wille and Isabelle Charmantier

Reviewed work(s):

Source: Isis, Vol. 103, No. 4 (December 2012), pp. 743-752

Published by: The University of Chicago Press on behalf of The History of Science Society

Stable URL: http://www.jstor.org/stable/10.1086/669048

Accessed: $13 / 02 / 2013$ 10:45

Your use of the JSTOR archive indicates your acceptance of the Terms \& Conditions of Use, available at

http://www.jstor.org/page/info/about/policies/terms.jsp

JSTOR is a not-for-profit service that helps scholars, researchers, and students discover, use, and build upon a wide range of content in a trusted digital archive. We use information technology and tools to increase productivity and facilitate new forms of scholarship. For more information about JSTOR, please contact support@jstor.org. 


\title{
Lists as Research Technologies
}

\author{
By Staffan Müller-Wille* and Isabelle Charmantier*
}

\begin{abstract}
The Swedish naturalist Carl Linnaeus (1707-1778) is famous for having turned botany into a systematic discipline, through his classification systems-most notably the sexual system - and his nomenclature. Throughout his life, Linnaeus experimented with various paper technologies designed to display information synoptically. The list took pride of place among these and is also the common element of more complex representations he produced, such as genera descriptions and his "natural system." Taking clues from the anthropology of writing, this essay seeks to demonstrate that lists can be considered as genuine research technologies. They possess a potential to generate research problems of their own but also pose limitations to inquiries that can be overcome only by the use of new media.
\end{abstract}

A LIST OF STIMULANTS particular to each continent (tea to Asia, coffee to Africa, chocolate to America, and beer to Europe); a list enumerating "equivocal names for fishes [nomina piscium aequivoca]"- - that is, names that designate other animals like birds or reptiles as well; and a list entitled "plants described in Linder's Art of Dyeing [örter $i$ Linders färgakonst beskrifna]": these are just three of the many lists one can find in a notebook that belonged to the naturalist Carl Linnaeus. He began to compile such lists in 1727, when he took up his medical studies at the University of Lund in southern Sweden, and he continued this practice while pursuing his studies at the University of Uppsala. ${ }^{1}$ Most of the information digested in these lists was culled from the libraries of professors Linnaeus lodged with - initially, as he later recalled, in secret and at night because he was afraid to ask for permission. ${ }^{2}$ As other contributions in this Focus section show, the list was a handy means to present and preserve knowledge in a concise and structured yet

\footnotetext{
* University of Exeter, College of Humanities, Amory Building, Rennes Drive, Exeter, Devon EX4 4RJ, Great Britain.

Research for this essay was generously supported by a Wellcome Trust Research Project Grant (no. 087231). We would also like to thank James Delbourgo and Bernie Lightman for critical input.

${ }^{1}$ Carl Linnaeus, "Manuscripta medica" (1727-1730), Linnean Society of London, Library and Archives, Linnaean Collections (hereafter cited as Linnaean Collections), Box GEN 2, Vol. 1, fols. 38v, 130v, 166v. The reference to "Linder's Art of Dyeing" is to Johan Linder, Swenska Färge-Konst (Stockholm: Johan Laur. Horrn, 1720). Here and throughout this essay, all translations are our own.

${ }^{2}$ Carl Linnaeus, Vita Caroli Linnaei: Carl von Linnés självbiografier, ed. Elis Malmeström and Arvid Hj. Uggla (Stockholm: Almqvist \& Wiksell, 1957), p. 61. This is an edition of several autobiographical manuscripts by Linnaeus.
}

Isis, 2012, 103:743-752

(C) 2012 by The History of Science Society. All rights reserved.

$0021-1753 / 2012 / 10304-0008 \$ 10.00$ 
open-ended manner. As instruments of structured synopsis, lists permeate the whole of Linnaeus's work, both in manuscript and in print. But lists would also become the main instrument for Linnaeus to explore territories of the unknown. List making, we intend to argue, can serve as a genuine "research-enabling technology." Often adopted from domestic, commercial, and administrative spheres and transposed to the world of learning, lists exhibit the potential to generate the same kind of epistemic surplus that is so familiar today from the physical instruments that populate laboratories. ${ }^{3}$

It is probably the deceptively simple and mundane character of lists that has hitherto kept historians of science from attending more to their epistemic functions. There is one notable exception, however. The very first written records in human history, Sumerian cuneiform tablets, include lexical lists-lists of names for stones, trees, animals, or artifacts-that have been given the technical term "Listenwissenschaft" ("list science"). What distinguishes these texts from other written records of the same period is that they arrange words in an order that does not serve any obvious purpose. Rather than representing economic transactions for administrative purposes, as the great majority of early Sumerian texts do, these lists group words by abstract categories (like "things of the heavens" and "things of the earth") or, in an even more strikingly "useless" manner, by initial sound.

In commenting on the considerable Sumerological literature that exists on Listenwissenschaft, the historical anthropologist Jack Goody has highlighted the cognitive effects of list making. We would like to consider his reflections before taking a closer look at Linnaeus's use of lists, because much of what Goody has to say in relation to Listenwissenschaft in ancient Sumer is of more general analytical value when exploring lists for their potential as research technologies. Goody's views can be summarized in three main points.

First, Sumerian Listenwissenschaft was in all likelihood the product of a very particular context. "Characteristically," Goody argues, such lists "developed as a kind of exercise or 'game' (in the context of scribal training)." Listenwissenschaft was therefore not strictly determined by then extant forms of list making. The alphabetical lists that make up the bulk of Listenwissenschaft, as Goody puts it, "are much less activity-oriented than inventories of estates or lists of contributions to sacrifices; they represent an abstraction, a de-contextualisation, a game." Second, in exploring the structure and meaning of lists, it is not enough to read them for their content in a linear and continuous fashion. "The list," Goody emphasizes, "depends on physical placement, on location." That is, a list has a geometry and creates a space of its own. The list "can be read in different directions, both sideways and downwards, up and down, as well as left and right; it has a clear cut beginning and a precise end, that is, a boundary, an edge, like a piece of cloth." And third, these structural features, according to Goody, also explain the peculiar cognitive effects that list making brings about. By providing places, directions, and boundaries, the list "encourages the ordering of . . . items, by number, by initial sound, by category, etc." Lists are not stable objects of contemplation; they invite manipulation through reordering. This produces a dialectical effect. On the one hand, lists, and the permutations they invite,

\footnotetext{
${ }^{3}$ Hans-Jörg Rheinberger, An Epistemology of the Concrete: Twentieth-Century Histories of Life (Durham, N.C.: Duke Univ. Press, 2010), p. 171.
} 
"crystallise problems of classification." On the other hand, by bringing "greater visibility to categories," lists may also construct a "conceptual prison.",

Linnaeus provides an ideal case for expanding on Goody's fundamental observations. Various forms of list were already widespread in the natural history literature that the young Linnaeus devoured. As Valentina Pugliano explains in her contribution to this Focus section, lists had become a common staple of early modern life, and there are quite a few indications that Linnaeus too lived his personal life by lists. Both precedents and personal habits left their mark on Linnaeus's research practice, but from early on he also showed a pronounced tendency to "play around" with lists. This quasi-experimental approach to list making played a crucial role in articulating and also limiting his taxonomic thinking. We will demonstrate this in three steps: first by examining the role of lists in Linnaeus's personal life, then by analyzing how these fed into his day-to-day taxonomic work, and finally by considering how list making shaped his ideas of the overall "order of nature."

That Linnaeus lived his life by lists is evident from the very first document of his that survives, a notebook dated 1725, when he attended the gymnasium in Växjö. It contains a class schedule, beginning Monday morning at 6 a.m. with an hour of mathematics and ending with a class of exercises and disputations on Saturday at 10 a.m. ${ }^{5}$ Likewise, Linnaeus's first autobiographical manuscript took the form of a list of the main events of his life, concisely described and precisely dated in the margin, up until his arrival in the mining town of Falun on 17 August 1734. All of his later autobiographies were designed in a similar way, either consisting of short paragraphs punctuated by dates, relocations, and encounters or listing personal achievements, especially publications, one by one (often with hilarious self-confidence). ${ }^{6}$ Apart from his own eventful life, important concerns that Linnaeus met by listing included noting potential patrons and correspondents, reporting the acquisition of books, and keeping records of income and expenses. A commonplace book Linnaeus began to compile in 1727 contains a list of "medical doctors in Sweden in the year 1728" that also features Kilian Stobaeus (1690-1742) and Olaus Rudbeck the younger (1660-1740), who eventually became his mentors. And later autobiographies, written when Linnaeus enjoyed a considerable reputation himself, contain enumerations of correspondents, arranged by geographical origin and importance. ${ }^{7}$ Linnaeus's student notebook "Manuscripta medica" incorporated a list of medical, zoological, botanical, and mineralogical books, duly recording prices as well. A handwritten catalogue of his own library of 1753 , organized by shelf location in his home, shows that Linnaeus, now holder of the Chair of Medicine and Botany at Uppsala University, had succeeded in acquiring many of these books. ${ }^{8}$ Finally, "Manuscripta medica" also features a neat list of the

\footnotetext{
${ }^{4}$ Jack Goody, The Domestication of the Savage Mind (Cambridge: Cambridge Univ. Press, 1977), pp. 94, 81, 94, 102.

${ }^{5}$ See the online edition of what is commonly called Linnaeus's Örtabok at http://www.vaxjo.se/ortaboken/. On lists' organization of early modern academic curricula see William Clark, Academic Charisma and the Origins of the Research University (Chicago: Univ. Chicago Press, 2006).

${ }^{6}$ Linnaeus, Vita Caroli Linnaei (cit. n. 2), pp. 44-57 (up to 17 Aug. 1734) and passim. For an example of Linnaeus's self-aggrandizing tendencies see Carl Linnaeus, A General View of the Writings of Linnaeus, ed. Richard Pulteney (London: J. Mawman, 1809), pp. 364-365.

${ }^{7}$ Carl Linnaeus, Commonplace Book (1727), Linnaean Collections, Box GEN 1, fol. 249r; and Linnaeus, Vita Caroli Linnaei, pp. 142-143, 153-154. See James Delbourgo, "Listing People," in this Focus section, on the practice of listing correspondents.

${ }^{8}$ Linnaeus, "Manuscripta medica" (cit. n. 1), Vol. 3, fol. 7r; and Carl Linnaeus, "Bibliotheca medica et botanica" (1753), Linnaean Collections, Box LM Bot.
} 
payments Linnaeus received for tutoring from 1729 to 1731 . There is also a loose sheet preserved in Linnaeus's papers that registers fees paid for tutoring, while a page of his journal covering his trip to Lapland in the summer of 1732 gives a detailed account of his expenses. ${ }^{9}$ After his marriage, Linnaeus seems to have given up on keeping track of his finances; in an autobiography written toward the end of his life, he thanks God for having "given him a wife that kept house while I worked." But occasional references to money spent or earned continue to permeate his autobiographical writing. ${ }^{10}$

Most of this list making for personal purposes is structured by references to specific points in time or space. Just like waste books in accounting, the lists reproduce the "accessional" order of a series of events or transactions in time or of spatially distributed items or persons. There is not much evidence that Linnaeus had any intimate knowledge of the high art of bookkeeping or was inspired by contemporaries who did. He certainly never engaged in double-entry bookkeeping. However, the notes he produced in the preparation of his scholarly works demonstrate that he not only employed lists in a waste book-like manner in this context as well, but also exploited them for the distillation of further lists of an increasingly abstract nature, just as one would use waste books in accounting for classifying and redistributing transactions according to some credit/debit scheme. ${ }^{11}$ His mundane practice of keeping records in the form of lists was thus inflected in specific ways to serve scholarly purposes.

An inconspicuous list of plant species in "Manuscripta medica" provides a good starting point to see in detail how this worked (see Figure 1). It is titled "Unfamiliar plants that I had not yet seen before I came to Skåne." It is written in a highly variable hand and several inks, suggesting that the entries were added one by one at different times and under different circumstances, perhaps sometimes in the field. The list was probably produced during the flowering season of $1728 . .^{12}$ Quite a few of the species named in this list reappear in a manuscript entitled "Spolia botanica," which is dated 5 May 1729-that is, roughly a year later. According to its preface, the latter manuscript presents a specimen of "botanical topography [topographia botanica]," listing species peculiar to three Swedish provinces: Smolandia, where Linnaeus grew up and attended gymnasium; Scania, where Lund is located; and Roslagen, a region northeast of Uppsala. The aim was to "draw conclusions with regard to diseases of the inhabitants, the situation and qualities of the country, and many other circumstances." The species are not presented, however, in the chronological or topographical order in which Linnaeus encountered them during his botanical excursions. For example, the first item in "Unfamiliar plants," "Cichorium sylv[ves-

\footnotetext{
${ }^{9}$ Linnaeus, "Manuscripta medica," Vol. 1, fol. 251v; Carl Linnaeus, "Collegie p-g[a]r Sommar terminen 1730," Linnaean Collections, Box LM Bio; and Linnaeus, "Iter Lapponicum," Linnaean Collections, Box LM Trav, fol. 7r.

${ }^{10}$ See e.g., Linnaeus, Vita Caroli Linnaei (cit. n. 2), p. 128, where he mentions that he spent 80,000 daler to buy two estates, Hammarby and Säfja, and that he received 100 ducater for his essay on the sex of plants from the St. Petersburg Academy of Sciences, as well as 3,500 daler from the "Russian Demidoffs" for private lecturing. The quotation regarding Linnaeus's wife is from the same autobiography; see Linnaeus, Vita Caroli Linnaei, p. 146.

${ }^{11}$ On parallels between bookkeeping and natural history note taking in the eighteenth century, especially during travel, see Anke te Heesen, "Accounting for the Natural World: Double-Entry Bookkeeping in the Field," in Colonial Botany: Science, Commerce, and Politics in the Early Modern World, ed. Londa Schiebinger and Claudia Swan (Philadelphia: Univ. Pennsylvania Press, 2005), pp. 237-251.

${ }^{12}$ Linnaeus, "Manuscripta medica" (cit. n. 1), Vol. 1, fol. 163r. The list is preceded by notes from Stobaeus's zoological lectures dated 1726. In 1726, Linnaeus was still in Växjö, however, and his first autobiography mentions private lecturing from Stobaeus for the winter and spring terms of 1727/1728; see Linnaeus, Vita Caroli Linnaei (cit. n. 2), p. 48.
} 


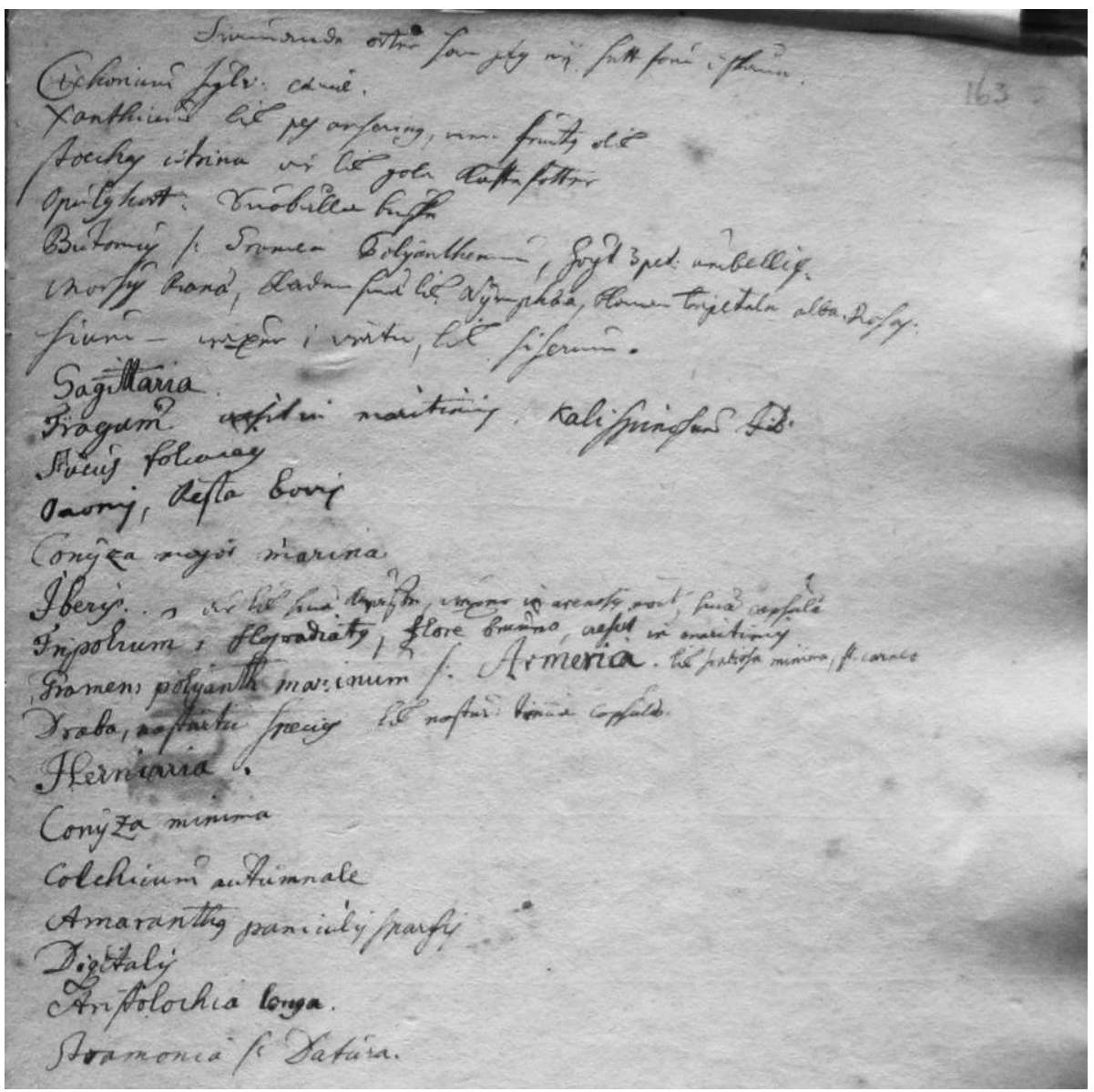

Figure 1. Page with a list of "Unfamiliar plants that I had not yet seen before I came to Skåne." Carl Linnaeus, "Manuscripta medica" (1727-1730), Linnean Society of London, Library and Archives, Linnaean Collections, Box LM GEN 2, Vol. 1, fol. 163r. By permission of the Linnean Society of London.

tris]," has become the fifty-fifth of "Scanian plants [Plantae Scanensis]" in "Spolia botanica"; the second, "Xanthium," the sixty-first; the third, "Stoechas citrina," the forty-fifth; and so on. ${ }^{13}$ The reason for these transpositions is Linnaeus's decision to arrange his Scanian plants according to the botanical system of Augustus Quirinus Rivinus (1652-1723), which classified plants by the number and arrangement of petals in the flower. That this decision related to certain abstractions is demonstrated by the fact that "Unfamiliar plants" contains quite a few remarks about the general appearance of the flowers observed, such as "like yellow cat paws [lik gula kattefötter]" or "like little crabs [lik små kräftor]." The original list from "Manuscripta medica" thus turns out to have served Linnaeus as an easily accessible reservoir of singular observations, made at certain times and places, that were

${ }^{13}$ Carl Linnaeus, "Spolia botanica," Linnaean Collections, Box LM Bot. The quotations here are from the annotated edition of this manuscript contained in Carl Linnaeus, Carl von Linnés Ungdomsskrifter, ed. Ewald Ährling (Stockholm: P. A. Norstedt, 1888), pp. 53-105, on pp. 57, 72-74. 
lying ready to be extracted from their original context for the purpose of particular projects. There is evidence that Linnaeus used a similar method when preparing Flora lapponica (1737) from material contained in the journal from his trip to Lapland. ${ }^{14}$

With "Spolia botanica," Linnaeus was reproducing a genre that was already well established in print-namely, that of floral catalogues of particular regions or gardens. ${ }^{15}$ Consisting basically of a list of species names-often complemented by references to the extant literature (so-called synonyms) and short remarks on where exactly the species could be found - such catalogues could be ordered according to quite various criteria: alphabetically, by season of flowering, or following a particular taxonomic system. What is striking about "Spolia botanica" is that Linnaeus chose to structure it using the three most important methods at the time. Whereas the plants from Scania were arranged according to Rivinus's system, Linnaeus followed the system of Joseph Pitton de Tournefort (1656-1708) for the plants of Smolandia and the system of John Ray (1627-1705) for those of Roslagen. Studying in one of Europe's scientific peripheries seems to have encouraged Linnaeus to dabble in each of the competing Continental systems, getting to know their respective advantages and disadvantages in the process. ${ }^{16}$ The same playfully experimental spirit can be detected in the first manuscript containing his own so-called sexual system of plant classification. In the flowering season of 1730, Linnaeus taught botany at the botanical garden in Uppsala, and three of the garden's manuscript catalogues from this time have survived. Two of these followed Tournefort's system, while the third follows what the title refers to as Linnaeus's "own method [methodum propriam]."17 Recognizing that these works are lists in the first place explains the apparent ease with which Linnaeus switched back and forth between various systems and eventually came up with his own. All he needed to do was to rearrange a limited set of species names according to the criteria provided by each system.

Linnaeus's delight in experimenting with arrangements of words on paper did not stop at the tried and tested genre of the catalogue, however. The catalogue, even if structured hierarchically by a taxonomic method, remains wedded to the simplest form of a list - that is, the arrangement of entries in a linear series that is read from top to bottom, while each individual entry is to be read from left to right. Even some of the more complex of Linnaeus's printed works follow this basic layout-for example, his Philosophia botanica, whose typographical clues orient and guide the reader. ${ }^{18}$ But Linnaeus also developed paper technologies that made use of paper space beyond these conventional

${ }^{14}$ Linnaeus, "Manuscripta medica" (cit. n. 1), Vol. 1, fol. 163r. Regarding Linnaeus's use of material from his Lapland journal in preparing Flora lapponica see Staffan Müller-Wille, "Joining Lapland and the Topinambes in Flourishing Holland: Center and Periphery in Linnaean Botany," Science in Context, 2003, 16:461-488, esp. pp. 467-468.

${ }^{15} \mathrm{On}$ this genre and its importance for the growth of botany see Alix Cooper, Inventing the Indigenous: Local Knowledge and Natural History in Early Modern Europe (Cambridge: Cambridge Univ. Press, 2007); on its roots in specimen lists exchanged among Renaissance collectors see Valentina Pugliano, "Specimen Lists: Artisanal Writing or Natural Historical Paperwork?" in this Focus section.

${ }^{16}$ Linnaeus, Carl von Linnés Ungdomsskrifter (cit. n. 13), p. 60: "Plantae Smolandicae Methodo Tournefortiana recensitae"; p. 76: "Plantae Roslagicae secundum Meth: Rajanum in ordinem digesta." On the three systems and the debates that turned on them see Phillip R. Sloan, "John Locke, John Ray, and the Problem of the Natural System," Journal of the History of Biology, 1972, 5:1-55.

${ }^{17}$ See Linnaeus, Carl von Linnés Ungdomsskrifter, pp. 107-149, 151-204; and Carl Linnaeus, Hortus Uplandicus, ed. Th. M. Fries (Upsala: Akademiska Boktrykeriet, 1899). All in all, there are five catalogues, with two further catalogues following the sexual system from 1731. Dedications indicate that Linnaeus produced some for patrons such as Rudbeck, whereas others may have been sold to students.

${ }^{18}$ Matthew D. Eddy, "Tools for Reordering: Commonplacing and the Space of Words in Linnaeus' Philosophia Botanica," Intellectual History Review, 2010, 20:227-252. 
restrictions. In a kind of inversion of the waste book method, Linnaeus early on began organizing his notes by first creating empty paper spaces for particular taxonomic units, mostly particular genera, and then filling up these spaces in succession with references and observations whenever he came across new information.

Over the course of his long career, Linnaeus tried out various paper technologies to create such spaces, including a filing system, interleaved copies of his own publications, and, toward the very end of his life, index cards. In the process, "Stoechas citrina"whose yellow flowers shaped like cat paws had excited Linnaeus's curiosity when he was botanizing around Lund-became a species of the genus Gnaphalium, alongside thirtyfour other European, North American, and African species. This method, as we have argued elsewhere, conferred substance and autonomy on the genus. The genus became a "box on paper" into which findings could be dropped one by one as they happened, slowly building up a fuller picture of its morphology, geographical distribution, and other qualities, such as medicinal or economic use. The genus thus ceased to be a logical category and acquired the reality of a gradually emergent landscape as though under the patient hand of a painter. In a sense, Linnaeus was attempting to do the impossible: to paint a picture using only words. ${ }^{19}$

It is Linnaeus's work on what he called the "fragments of a natural method [ fragmenta methodi naturalis]" that provides the best example of the powerful potential that list making has to open up new research agendas, while also demonstrating its limitations. Already in his first publication, the Systema naturae (1735), Linnaeus had warned against taking his sexual system of plants for a "natural system" and announced his intention to publish "fragments" of such a system soon. This happened three years later, in a separate section of Classes plantarum, a publication in which Linnaeus assembled and correlated all of the major taxonomic systems that had been published so far. In comparison with these systems, which derived their articulation into classes and orders through a series of straightforward distinctions, the "fragments of a natural method" took a peculiar form. They consisted of forty-five lists of genera names, each designated by a heading as a separate, numbered "order." The number of genera brought under each of these orders varies widely, from four to seventy-nine, and the individual lists are arranged in two columns on each page. Some genera names are followed by question marks and some lists by remarks like "Perhaps Parnassium could be placed here?"20 Later editions of the fragments, in Philosophia botanica (1751) and in the sixth edition of Genera plantarum (1764), provided proper names for the "natural orders," such as "palms" or "orchids." They also demonstrate that Linnaeus not only added more and more genera, and created new orders, but that he also constantly changed his mind about which genus belonged to which order, resulting in significant rearrangements. ${ }^{21}$

This is not the place to go into Linnaeus's differentiation of "artificial" and "natural"

\footnotetext{
${ }^{19}$ Carl Linnaeus, "Species plantarum Ms.” (1753), Linnaean Collections, Box LM Bot, fol. 401 (redesignation of "Stoechas citrina"); and Staffan Müller-Wille and Isabelle Charmantier, "Natural History and Information Overload: The Case of Linnaeus," Studies in History and Philosophy of Biological and Biomedical Sciences, 2012, 43:4-15. For an interesting account of the relationship of writing and drawing see Tim Ingold, Lines: A Brief History (New York: Routledge, 2007), Ch. 5.

${ }^{20}$ Carl Linnaeus, Systema naturae, sive regna tria naturae systematice proposita per classes, ordines, genera, \& species (Leiden: Theodor Haak, 1735), "Observationes in Regnum Vegetabile," aph. 12 (unpaginated); and Linnaeus, Classes plantarum seu systemata plantarum omnia a fructificatione desumta (Leiden: Wishoff, 1738), pp. $485-514$.

${ }^{21}$ For an analysis of these changes see Arthur J. Cain, "Linnaeus's 'Ordines naturales,"” Archives of Natural History, 1993, 20:405-415.
} 
systems. What interests us here is how he used lists to represent taxonomic relationships that were not linear but, according to his own statement in 1751, connected "all plants through mutual affinities, like territories on a geographic map."22 This was a decisive break with the age-old idea of a scale of beings, and it seems uniquely incompatible with the basic form of a list. The autograph traces left from Linnaeus's attempts to work out the contours of the natural system show, however, that he remained wedded to this form. The printed pages of Linnaeus's personal copies of Classes plantarum, Philosophia botanica, and Genera plantarum are filled with handwritten annotations, adding and deleting genera from "natural orders," moving them from one order to another, and creating additional series of genera attached to the beginning or end of one of the preexisting orders, sometimes at a right angle (see Figure 2).

Working out a network of relationships by creating and moving around small, isolated bits of a linear chain must have been an extremely cumbersome and circular business. And it mattered, as the "natural method" was supposed to depict relations of equivalence that were of central concern both for the exchange of specimens with other naturalists and for Linnaeus's grand project of creating "a miniature mercantile empire within a European state." ${ }^{23}$ We have emphasized the exploratory nature of Linnaeus's work on the natural system, but it also served a practical purpose. Linnaeus hoped that the identification of natural orders would help him to find domestic substitutes for valuable plant species that had to be imported from exotic countries. In this sense, Linnaeus's work on the natural system was a sophisticated way of charting the terrain for future discovery and improvement. ${ }^{24}$

Linnaeus stuck to the cumbersome method of using lists to explore the natural system for the rest of his life. It fell to one of his students to establish a better way of working. In 1792, Paul Dietrich Giseke (1741-1796) published a posthumous edition of Linnaeus's lectures on the "natural orders of plants" that included a double-folio foldout chart entitled "Genealogical-Geographical Table of Plant Affinities." The chart no longer represented "natural orders" through lists of words but instead used irregular circles of varying size (corresponding to the number of genera included) that were arranged in a manner resembling an archipelago. ${ }^{25}$ This way of representing "plant affinities" graphically was eagerly taken up by other naturalists, and the early nineteenth century abounds with similar map- or network-like representations. ${ }^{26}$ What was needed to precipitate this revolution in representing the order of nature was thus not only a change in paradigm, but also a change in the medium of representation. With

\footnotetext{
${ }^{22}$ Carl Linnaeus, Philosophia botanica in qua explicantur fundamenta botanica cum definitionibus partium, exemplis terminorum, observationibus rariorum (Stockholm: Kiesewetter, 1751), p. 27. On Linnaeus's differentiation of "artificial" and "natural" systems see Staffan Müller-Wille, "Collection and Collation: Theory and Practice of Linnaean Botany," Stud. Hist. Phil. Biol. Biomed. Sci., 2007, 38:541562.

${ }^{23}$ Lisbet Koerner, Linnaeus: Nature and Nation (Cambridge, Mass.: Harvard Univ. Press, 1999), p. 144; on equivalence and specimen exchange see Staffan Müller-Wille, "Nature as a Marketplace: The Political Economy of Linnaean Botany," in Oeconomies in the Age of Newton, ed. Margaret Schabas and Neil de Marchi (Durham, N.C.: Duke Univ. Press, 2003), pp. 155-173.

${ }^{24}$ See Vera Keller, "The 'New World of Sciences': The Temporality of the Research Agenda and the Unending Ambitions of Science," in this Focus section, for the importance of projective list making in early modern natural history and natural philosophy.

${ }^{25}$ Carl Linnaeus, Praelectiones in ordines naturales plantarum, ed. Paul Dietrich Giseke (Hamburg: Benjamin Gottlieb Hoffmann, 1792), p. 623.

${ }^{26}$ On this epochal transformation in natural history see Hans-Jörg Rheinberger, "Aspekte des Bedeutungswandels im Begriff organismischer Ähnlichkeit vom 18. zum 19. Jahrhundert," History and Philosophy of the Life Sciences, 1986, 8:237-250; and Giulio Barsanti, La scala, la mappa, l'albero: Immagini e classificazioni della natura fra sei e ottocento (Florence: Sansoni, 1992).
} 


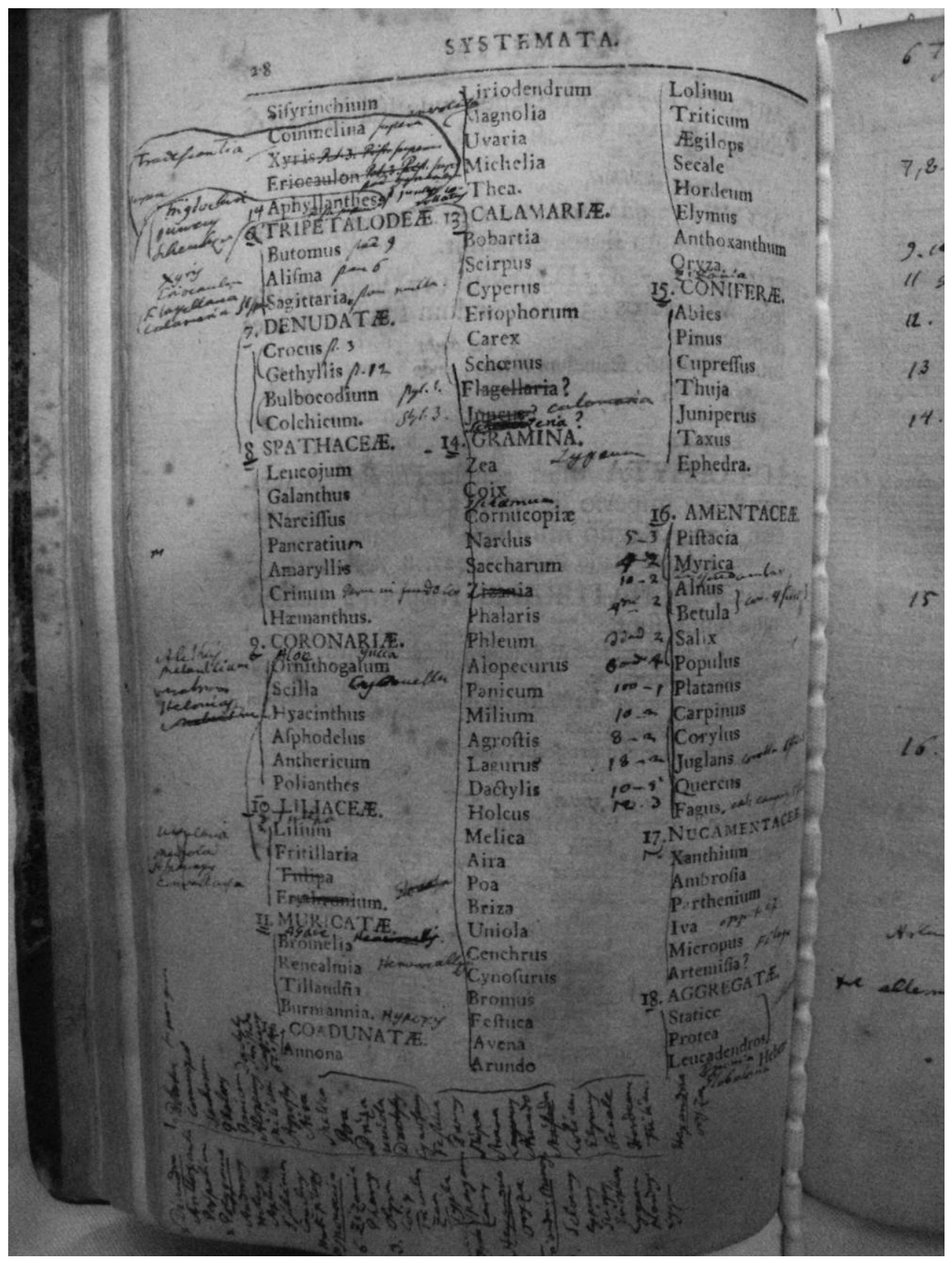

Figure 2. Page presenting part of the "natural method" from Carl Linnaeus, Philosophia botanica (Stockholm: Kiesewetter, 1751), with annotations by the author. Linnean Society of London, Library and Archives, Linnaean Collections, call no. BL80, p. 28. By permission of the Linnean Society of London. 
Linnaeus, the natural system had been the preserve of carefully initiated naturalists who, comparing their lists with his linear series of words, might "see" relationships emerging between "natural orders." With Giseke's map, these relationships were made explicit to anyone who looked at them.

We have expanded on the case of Linnaeus not only to demonstrate the analytical value of Goody's observations on Listenwissenschaft but also to argue for their explanatory value. The transformation of taxonomic thinking around 1800, sketched in the previous paragraph, was perhaps most notably described by Arthur Lovejoy in his classic The Great Chain of Being (1936). But his explanation for this transformation-namely, that the ancient idea of a continuous scale of nature broke down "largely from its own weight"remains obscure..$^{27}$ Attending to lists and other writing technologies, such as catalogues or index cards, for what they are-material tools for organizing the acquisition and accumulation of knowledge - can help us construct a more detailed and convincing account of this important transition in conceptions of the natural order.

${ }^{27}$ Arthur O. Lovejoy, The Great Chain of Being: A Study of the History of an Idea (1936; Cambridge, Mass.: Harvard Univ. Press, 1990), p. 245. For a critical reevaluation of Lovejoy's grand claim see Nick Hopwood, Simon Schaffer, and Jim Secord, "Seriality and Scientific Objects in the Nineteenth Century," History of Science, 2010, 48:251-285. 